\title{
A height-diameter model for Pinus radiata D. Don in Galicia (Northwest Spain)
}

\author{
Carlos A. López Sánchez ${ }^{\text {** }}$ Javier Gorgoso Varelaa ${ }^{a}$ Fernando Castedo Dorado ${ }^{\mathrm{a}}$, Alberto Rojo Alboreca ${ }^{\mathrm{a}}$, \\ Roque Rodríguez Soalleiro ${ }^{\mathrm{b}}$, Juan Gabriel Álvarez González ${ }^{\mathrm{a}}$ and Federico Sánchez Rodríguez ${ }^{\mathrm{b}}$

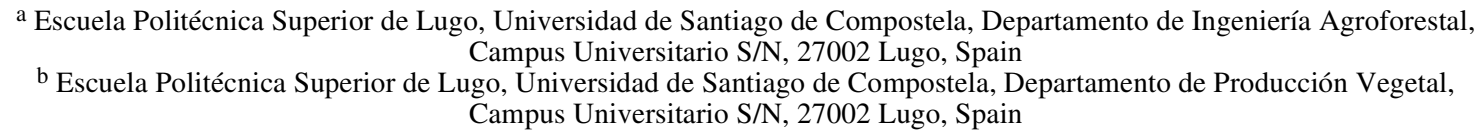

(Received 6 August 2001; accepted 12 August 2002)

\begin{abstract}
A total of 26 models that estimate the relationship between height and diameter in terms of stand variables (basal area, quadratic mean diameter, maximum diameter, dominant diameter, dominant height, arithmetic mean height, age, number of trees per hectare and site index), were fitted to data corresponding to 9686 trees, using linear and non-linear regression procedures. The precision of the models was then evaluated by cross-validation. The data were collected during two inventories of 182 permanent plots of radiata pine (Pinus radiata D. Don) situated throughout Galicia, in the Northwest of Spain. Comparison of the models was carried out by studying the coefficient of determination, bias, mean square error, Akaike's information criterion and by using a F-test to compare predicted and observed values. Best results were obtained with those models that included any independent variable related to the height of the stand (mean or dominant height), although this implies a greater sampling effort for its application. The model of Tomé gave the best height estimates.
\end{abstract}

Pinus radiata D. Don / forest modelling / Galicia / height-diameter relationship

Résumé - Un modèle hauteur-diamètre pour Pinus radiata D. Don en Galice (nord-ouest de l'Espagne). Vingt-six modèles prenant en compte le rapport hauteur-diamètre en fonction des variables de masse (diamètre maximal, diamètre dominant, hauteur dominante, hauteur moyenne arithmétique, âge, nombre d'arbres par hectare, qualité du site, etc.), ont été évalués par rapport aux données relatives à 9686 arbres, grâce à des procédures de régression linéaire et non linéaire. La précision des modèles a ensuite été évaluée par validation croisée. Les données correspondent à deux inventaires réalisés sur 182 parcelles permanentes de Pinus radiata D. Don réparties dans toute la Galice, au nord-ouest de l'Espagne. La comparaison des modèles a été effectuée suite à l'étude du coefficient de détermination, du biais, de l'écart quadratique moyen et du critère d'information d'Akaike. Un F-Test a été utilisé pour comparer les valeurs prévues et observées. Les meilleurs résultats ont été obtenus avec les modèles comprenant une variable indépendante en lien avec la hauteur de la masse (moyenne ou hauteur dominante), bien que cela implique un gros effort d'échantillonnage pour son application. Le modèle de Tomé a permis d'obtenir les meilleures évaluations de hauteur.

Pinus radiata D. Don / modélisation de forêt / Galice / rapport hauteur-diamètre

\section{INTRODUCTION}

Diameter at breast height and total height are the most commonly measured variables in forest inventories. Total height is less frequently used in the development of forest models than diameter, as it is hard and costly to measure, and as a result inaccurate measurements are often made [14]. A single sample of height measurements is therefore usually taken and equations that relate the two variables fitted [26].
These height-diameter relationships are applied to evenaged stands and can be fitted to linear functions, such as second-order polynomial equations [18, 23, 28, 31], or, more usually, to non-linear models [19]. However, the height curves thus obtained for stands do not adapt well to all the possible situations that can be found within a stand. This is for a number of reasons:

1. The height curve of an even-aged stand does not remain constant and is displaced in an increasing direction, for both

* Correspondence and reprints

Tel.: (34) 982 252231; fax: (34) 982 241835; e-mail: calopez@lugo.usc.es 
variables, with age $[2,3,12,24,39]$, i.e. trees that have the same diameter at different times belong to sociologically different classes. The height-diameter curve of a stand is therefore a state function, which is different from the curve of height growth of the stand with age.

2. The height curves for good quality sites will have steeper slopes than those for poor quality sites [34].

3. Clearly, for a particular height, trees that grow in high density stands will have smaller diameters than those growing in less dense stands, because of greater competition among individuals $[4,25,34,42]$.

Therefore, in even-aged stands, in which there is great variation in age, quality and density between cohorts, a single $h-d$ relationship for the whole stand would be the result of many different $h-d$ relationships, with high variability around the regression line. In such cases, to reduce the error involved in estimating heights, the use of a generalised heightdiameter equation is recommended, which models the changes in the height-diameter relationship over time [14].

The aim of the present study is to find an equation that can be used to predict the height-diameter relationship in Pinus radiata stands in Galicia (north-western Spain) by considering a number of stand variables (dominant diameter, dominant height, age, density, site index, etc.), which may influence the relationship.

\section{MATERIALS AND METHODS}

\subsection{Data used}

For this study, total height and diameter at breast height data were used from 355 inventories of a set of 182 permanent plots that the Escuela Politécnica Superior de Lugo (University of Santiago de Compostela) has established in pure, even-aged stands of Pinus radiata D. Don throughout Galicia. The plots are square or rectangular, with dimensions varying between $25 \times 25$ and $30 \times$ 40 metres. The number of trees per plot ranges between 30 and 145 depending on the stand density. The plots were installed to give the greatest variety of combinations of age, density and site quality.

Data were collected in two stages; the plots were established and the first inventory carried out between 1995 and 1996, and the second inventory was carried out between 1998 and 1999. Between the two measurements, plots located in thinned stands were remeasured, so that some plots were inventoried three times.

In each plot the diameter at breast height of all of the trees was crosswise measured, using calipers, to the nearest millimetre. Heights were measured using a Blume-Leiss hypsometer in a sample of 30 trees chosen at random from all of the trees in the plot.

The following stand variables were calculated from the data collected in the inventories: basal area, quadratic mean diameter, maximum diameter, dominant diameter and height (using Assman's criterion for both), mean height, age (because the stands are evenaged, the age was calculated from the year of planting), density and site quality, defined as the dominant height (expressed in metres) that the stand reaches at 20 years and determined from the site quality curves available for this specie in Galicia [35].

The mean, maximum and minimum values and standard deviations of the main dendrometric and stand variables are given in table I and table II, respectively.
Table I. Characteristics of the tree samples used for model fitting.

\begin{tabular}{lcccc}
\hline \multicolumn{5}{c}{$\begin{array}{c}\text { Sample for model fitting } \\
(N=9686)\end{array}$} \\
\hline Variable & Mean & Maximum & Minimum & Standard deviation \\
\hline$h$ & 17.29 & 36.40 & 3.00 & 6.19 \\
$d$ & 23.90 & 62.95 & 5.00 & 11.93 \\
\hline
\end{tabular}

Table II. Characteristics of the plots from which the samples of trees used for model fitting were taken.

\begin{tabular}{lcccc}
\hline \multicolumn{5}{c}{$\begin{array}{c}\text { Sample for model fitting } \\
(N=9686)\end{array}$} \\
\hline Variable & Mean & Maximum & Minimum & Standard deviation \\
\hline$G$ & 53.66 & 218.50 & 0.98 & 39.46 \\
$d_{\mathrm{g}}$ & 23.70 & 53.84 & 6.04 & 9.66 \\
$D_{\max }$ & 38.82 & 80.70 & 11.10 & 13.85 \\
$D_{0}$ & 33.49 & 64.75 & 10.33 & 11.11 \\
$H_{0}$ & 19.98 & 34.02 & 5.80 & 5.70 \\
$H_{\mathrm{m}}$ & 17.13 & 30.17 & 3.95 & 5.29 \\
$t$ & 23.28 & 41.00 & 5.00 & 8.50 \\
$N$ & 996.11 & 4864 & 216.70 & 550.42 \\
$I S$ & 18.97 & 26.8 & 13.00 & 3.24 \\
\hline
\end{tabular}

\subsection{Models analysed}

A large number of generalised height-diameter equations have been reported in the forestry literature, many of which have been developed for a particular species or specific area. For this study, we have considered the most commonly used, as well as those developed for Pinus radiata. Finally, we analysed the 26 generalised heightdiameter equations given in table III; these are classified according to the real sampling effort in the following groups:

Group 1: Low sampling effort models, including those models which need diameter measurements and knowledge of age in some cases.

Group 2: Medium sampling effort models, including models which need measurements of diameter and of a sample of tree heights.

Group 3: High sampling effort models, including models which need the knowledge or measurements of stand age as well.

The terminology used in the description of the models is as follows: $h=$ total height of tree, in $\mathrm{m} ; d=$ diameter at breast height over bark, in cm; $G=$ basal area of the stand, in $\mathrm{m}^{2} \mathrm{ha}^{-1} ; d_{\mathrm{g}}=$ quadratic mean diameter of the stand, in $\mathrm{cm} ; D_{\max }=$ maximum diameter of the stand, in $\mathrm{cm} ; D_{0}=$ dominant diameter of the stand, in $\mathrm{cm} ; H_{0}=$ dominant height of the stand, in $\mathrm{m} ; H_{\mathrm{m}}=$ mean height of the stand, in $\mathrm{m} ; t=$ age of the stand, in years; $N=$ number of trees per hectare; $S I=$ site index, in $\mathrm{m} ; \log =\log$ arithm $\mathrm{m}_{10} ; \ln =$ natural logarithm; $b_{\mathrm{i}}=$ regression coefficients to be determined by model fitting.

The measurement of the mean height requires a greater sampling effort that may allow the limitation of future use of models that include this variable. To avoid this problem, it has been obtained a relationship between the mean height and the dominant height of the stand, the latter value being easier to obtain on field. The resulting equation is the following: $H_{\mathrm{m}}=-1.4497+0.9295 \cdot H_{\mathrm{o}}\left(R^{2}\right.$ adj $=$ $0.9504 ; M S E=1.4860$ ). 
Table III. Generalized height-diameter models analyzed.

\begin{tabular}{|c|c|c|}
\hline Author(s) & Expression & Group \\
\hline Curtis [13] & $h=10^{\left(b_{0}+b_{1} \cdot \frac{1}{d}+b_{2} \cdot \frac{1}{t}+b_{3} \cdot \frac{1}{d_{g} \cdot t}\right)}$ & 1 \\
\hline Cox (I) [11] & $h=\mathrm{e}^{\left(b_{0}+b_{1} \cdot \ln d_{g}+b_{2} \cdot \ln N+b_{3} \cdot \sqrt{d}\right)}$ & 1 \\
\hline $\begin{array}{l}\text { Clutter } \\
\text { and Allison [10] }\end{array}$ & $\left.h=1.3+10^{\left(b_{0}+b_{1} \cdot \frac{1}{d}+b_{2} \cdot \frac{1}{\sqrt{t}}+b_{3} \cdot \frac{1}{d \cdot \sqrt{t}}+b_{4} \log N\right.} \sqrt{\sqrt{t}}\right)$ & 1 \\
\hline Mønness [30] & $h=1.3+\left[b_{0} \cdot\left(\frac{1}{d}-\frac{1}{D_{0}}\right)+\left(\frac{1}{H_{0}-1.3}\right)^{1 / 3}\right]$ & 2 \\
\hline Cañadas et al. I [8] & $h=1.3+\left(H_{0}-1.3\right) \cdot\left(\frac{d}{D_{0}}\right)^{b_{0}}$ & 2 \\
\hline $\begin{array}{l}\text { Cañadas et al. } \\
\text { II [8] }\end{array}$ & $h=1.3+\frac{d}{\frac{D_{0}}{H_{0}-1.3}+b_{0} \cdot\left(D_{0}-d\right)}$ & 2 \\
\hline $\begin{array}{l}\text { Cañadas et al. } \\
\text { III [8] }\end{array}$ & $h=1.3+\left(H_{0}-1.3\right) \cdot \frac{1-\mathrm{e}^{b_{0} \cdot d}}{1-\mathrm{e}^{b_{0} \cdot D_{0}}}$ & 2 \\
\hline $\begin{array}{l}\text { Cañadas et al. } \\
\text { IV [8] }\end{array}$ & $h=1.3+\left[b_{0} \cdot\left(\frac{1}{d}-\frac{1}{D_{0}}\right)+\left(\frac{1}{H_{0}-1.3}\right)^{1 / 2}\right.$ & 2 \\
\hline Gaffrey [15] & $h=1.3+\left(H_{0}-1.3\right) \cdot \mathrm{e}^{b_{0} \cdot\left(1-\frac{d_{g}}{d}\right)+b_{1} \cdot\left(\frac{1}{d_{g}}-\frac{1}{d}\right)}$ & 2 \\
\hline Sloboda et al. [38] & $h=1.3+\left(H_{\mathrm{m}}-1.3\right) \cdot \mathrm{e}^{\left(b_{0} \cdot\left(1-\frac{d}{d_{g}}\right)\right)} \cdot \mathrm{e}^{b_{1} \cdot\left(\frac{d}{d_{g}}-\frac{1}{d}\right)}$ & 2 \\
\hline Harrison et al. [16] & $h=H_{0} \cdot\left(1+b_{0} \cdot \mathrm{e}^{b_{1} \cdot H_{0}}\right) \cdot\left(1-\mathrm{e}^{\frac{-b_{2} \cdot d}{H_{0}}}\right)$ & 2 \\
\hline $\begin{array}{l}\text { Castedo et al. [9] } \\
\text { Mod.* }\end{array}$ & $h=1.3+\frac{b_{0} \cdot H_{0}^{b_{1}} \cdot\left(H_{0}-1.3\right)}{\left(\left|\frac{D_{0}-d}{d}\right|\right)^{b_{2}}}$ & 2 \\
\hline $\begin{array}{l}\text { Pienaar [33] } \\
\text { Mod.** }\end{array}$ & $h=b_{0} \cdot H_{0} \cdot\left(1-\mathrm{e}^{\frac{-b_{1} \cdot d}{d_{g}}}\right)^{b_{2}}$ & 2 \\
\hline $\begin{array}{l}\text { Hui and Gadow } \\
{[21]}\end{array}$ & $h=1.3+b_{0} \cdot H_{0}^{b_{1}} \cdot d^{b_{2} \cdot H_{0}^{b_{3}}}$ & 2 \\
\hline Mirkovich [29] & $h=1.3+\left(b_{0}+b_{1} \cdot H_{0}-b_{2} \cdot d_{\mathrm{g}}\right) \cdot \mathrm{e}^{-b_{3} / d}$ & 2 \\
\hline $\begin{array}{l}\text { Schröder and } \\
\text { Álvarez I [37] *** }\end{array}$ & $h=1.3+\left(b_{0}+b_{1} \cdot H_{0}-b_{2} \cdot d_{\mathrm{g}}\right) \cdot \mathrm{e}^{-b_{3} / \sqrt{d}}$ & 2 \\
\hline $\begin{array}{l}\text { Cox III [11] } \\
\text { Mod. **** }\end{array}$ & $h=H_{\mathrm{m}} \cdot\left[\begin{array}{l}b_{0}+b_{1} \cdot H_{\mathrm{m}}+b_{2} \cdot \frac{H_{\mathrm{m}}}{d_{\mathrm{g}}}+b_{3} \cdot d+ \\
+b_{4} \cdot \frac{N}{\frac{d_{\mathrm{g}} \cdot\left(H_{\mathrm{m}} \cdot d_{\mathrm{g}}\right)}{d}}\end{array}\right]$ & 2 \\
\hline $\begin{array}{l}\text { Schröder and } \\
\text { Álvarez II [37] *** }\end{array}$ & $h=1.3+\left(b_{0}+b_{1} \cdot H_{0}-b_{2} \cdot d_{\mathrm{g}}+b_{3} \cdot G\right) \cdot \mathrm{e}^{-b_{4} / \sqrt{d}}$ & 2 \\
\hline
\end{tabular}

Cox II [11]

Mod. $1 * * * *$

Cox II [11]

Mod. $2 * * * *$

Tomé [40]

Bennet

and Clutter [5]

Lenhart [27]

Amateis et al. [1]

Burkhart

and Strub [6]

Pascoa [32]

$$
\begin{gathered}
h=b_{0}+b_{1} \cdot H_{\mathrm{m}}+b_{2} \cdot d_{\mathrm{g}}^{0.95}+b_{3} \cdot \mathrm{e}^{-0.08 \cdot d}+ \\
+b_{4} \cdot H_{\mathrm{m}}^{3} \cdot \mathrm{e}^{-0.08 \cdot d}+b_{5} \cdot d_{\mathrm{g}}^{3} \cdot \mathrm{e}^{-0.08 \cdot d} \\
h=b_{0}+b_{1} \cdot H_{\mathrm{m}}+b_{2} \cdot d_{\mathrm{g}}+b_{3} \cdot \mathrm{e}^{b_{4} \cdot d}+ \\
+b_{5} \cdot H_{\mathrm{m}}^{b_{6}} \cdot \mathrm{e}^{b_{4} \cdot d}+b_{7} \cdot d_{\mathrm{g}}^{b_{8}} \cdot \mathrm{e}^{b_{4} \cdot d} \\
\left.h=H_{0} \cdot \mathrm{e}^{\left(b_{0}+b_{1} \cdot H_{0}+b_{2} \cdot \frac{N}{1,000}+b_{3} \cdot t\right)}\right)\left(\frac{1}{d}-\frac{1}{D_{0}}\right) \\
h=\mathrm{e}^{b_{0}+b_{1} \cdot I S+b_{2} \cdot \frac{N}{100}+b_{3} \cdot \frac{1}{t}+b_{4} \cdot \frac{1}{d}}
\end{gathered}
$$$$
h=\frac{H_{0}}{\mathrm{e}^{b_{0}+\left(\frac{1}{d}-\frac{1}{D_{\max }}\right) \cdot\left(b_{1}+b_{2} \cdot \ln N+b_{3} \cdot \frac{1}{t}+b_{4} \cdot \ln H_{0}\right)}}
$$$$
h=b_{0} \cdot H_{0}^{b_{1}} \cdot 10^{\left(\frac{b_{2}}{t}+\left(\frac{1}{d}-\frac{1}{D_{\max }}\right) \cdot\left(b_{3}+b_{4} \cdot \frac{\log N}{t}\right)\right)}
$$$$
h=\mathrm{e}^{b_{0}+b_{1} \cdot \ln H_{0}+b_{2} \cdot \frac{1}{t}+b_{3} \cdot \frac{\ln N}{d}+b_{4} \cdot \frac{1}{d \cdot t}+b_{5} \cdot \frac{1}{d}}
$$$$
h=b_{0} \cdot H_{0}^{b_{1}} \cdot G^{b_{2}} \cdot N^{b_{3}} \cdot \mathrm{e}^{\frac{b_{4}}{t}+\frac{b_{5}}{d}}
$$

* Generalized height-diameter function obtained relating the parameters of $S_{\mathrm{BB}}$ function [22] to stand variables.

** Modification of the original model omitting the parameter associated with the number "e" as its value was close to one and the asymptotic standard error was very high.

*** Modifications of the model of Mirkovich [29] to reduce the bias in the height estimates.

**** Modification of the original model using the arithmetic mean height of the stand $\left(H_{\mathrm{m}}\right)$ as the independent variable instead of the mean value of the maximum and minimum stand heights, which are harder to measure in the field.

Estimations obtained with the above equation (instead of the observed values) were used for the adjustment of the models that include mean height of the stand $\left(H_{\mathrm{m}}\right)$ as an independent variable.

\subsection{Statistical analysis}

Most of the models described above are non-linear, therefore model fitting was carried out with the NLIN procedure of the SAS/ STAT $^{\text {TM }}$ statistical programme [36] using the Gauss-Newton algorithm [17]. The initial values of the parameters for starting the iterative procedure were obtained, where possible, by previously linearizing the equation and fitting it to the data by ordinary least squares, using the REG procedure of the same statistical programme. When it was not possible to linearize the equation, values obtained by other authors in similar studies were used.

Comparison of the model estimates was based on graphical and numerical analysis of the residuals and values of four statistics: the bias $\hat{Z}_{i}$, which evaluates the deviation of the model with respect to the observed values; the mean square error $(M S E)$, which analyses the precision of the estimates; the adjusted coefficient of determination $\left(R^{2}{ }_{\text {adj }}\right)$, which reflects the part of the total variance that is explained by the model and which takes into account the number of parameters that it is necessary to estimate; and finally, the relative values of Akaike's information criterion $\left(\Delta_{j}\right)$, which is an index for 
Table IV. Values of the statistics for fitting and cross-validation for group 1 models.

\begin{tabular}{|c|c|c|c|c|c|c|c|c|c|c|c|}
\hline \multirow[t]{3}{*}{ MODELS } & \multicolumn{5}{|c|}{ FIT } & \multicolumn{6}{|c|}{ CROSS - VALIDATION } \\
\hline & \multirow[t]{2}{*}{ Variables } & \multirow[t]{2}{*}{$R_{\text {adj }}^{2}$} & \multirow[t]{2}{*}{ Bias } & \multirow[t]{2}{*}{$M S E$} & \multirow{2}{*}{$\Delta_{j}$} & \multirow[t]{2}{*}{$M E F_{\text {adj }}$} & \multicolumn{2}{|c|}{ pred. vs. obs. F-Test } & \multirow[t]{2}{*}{ Bias } & \multirow[t]{2}{*}{$M S E$} & \multirow[t]{2}{*}{$\Delta_{j}$} \\
\hline & & & & & & & F VAL. & $\operatorname{Pr}>F$ & & & \\
\hline Curtis [13] & $d, d_{\mathrm{g}}, t$ & 0.7515 & 0.0567 & 9.5314 & 10727.1099 & 0.7512 & 17.56 & $<0.0001$ & 0.0569 & 9.5393 & 10720.3448 \\
\hline Cox I [11] & $d, d_{\mathrm{g}}, N$ & 0.7362 & -0.0563 & 10.1168 & 11304.4445 & 0.7359 & 18.71 & $<0.0001$ & -0.0565 & 10.1272 & 11299.5841 \\
\hline Clutter and Allison [10] & $d, t, N$ & 0.7317 & 0.0382 & 10.2890 & 11468.9820 & 0.7311 & 6.87 & 0.001 & 0.0387 & 10.3093 & 11473.2493 \\
\hline
\end{tabular}

selecting the best model, based on minimising the Kullback-Liebler distance [7]. The expressions for these statistics are as follows:

Bias: $\bar{E}=\frac{\sum_{i=1}^{N}\left(Y_{i}-\hat{Y}_{i}\right)}{N}$;

Mean square error: $M S E=\frac{\sum_{i=1}^{N}\left(Y_{i}-\hat{Y}_{i}\right)^{2}}{N-p}$;

Coefficient of determination: $R^{2}=1-\frac{\sum_{i=1}^{N}\left(Y_{i}-\hat{Y}_{i}\right)^{2}}{\sum_{i=1}^{N}\left(Y_{i}-\bar{Y}_{i}\right)^{2}}$;

Adjusted coefficient of determination:

$R_{\text {adj }}^{2}=1-\left(1-R^{2}\right) \cdot\left(\frac{N-1}{N-p}\right) ;$

Akaike's information criterion differences:

$$
\Delta_{j}=N \cdot \ln \hat{\sigma}_{j}^{2}+2 \cdot K_{j}-\min \left(N \cdot \ln \hat{\sigma}_{j}^{2}+2 \cdot K_{j}\right)
$$

where $Y_{i}, \hat{Y}_{i}$ and $\bar{Y}_{i}$ are the observed, predicted and mean values of heights, respectively; $N$ is the total number of data used in fitting the model; $p$ the number of parameters to estimate; $R^{2}$ the coefficient of determination; $K_{j}$ the number of parameters in model $j$ plus $1\left(K_{j}=\right.$ $p+1)$ and $\hat{\sigma}^{2}$ an estimate of the error variance of model $j$, calculated

as: $\hat{\sigma}^{2}=\frac{\sum_{i=1}^{N}\left(Y_{i}-\hat{Y}_{i}\right)^{2}}{N}$.

To analyse the predictive capacity of the equations a cross-validation was carried out. The values of the prediction residuals obtained in the cross-validation were used to calculate the bias, mean square error (MSE), Akaike's information criterion differences $\left(\Delta_{i}\right)$ and the precision of the model $\left(M E F_{\mathrm{adj}}\right)$ :

$$
M E F_{\text {adj }}^{2}=1-\frac{\sum_{i=1}^{N^{\prime}}\left(\mathrm{Z}_{\mathrm{i}}-\hat{Z}_{i}\right)^{2}}{\sum_{i=1}^{N^{\prime}}\left(\mathrm{Z}_{\mathrm{i}}-\overline{\mathrm{Z}}_{i}\right)^{2}} \cdot\left(\frac{N^{\prime}-1}{N^{\prime}-p}\right)
$$

where $Z_{i}$ and $\bar{Z}_{i}$ are the observed and mean values of heights, respectively, $\hat{Z}_{i}$ is the prediction residual; $N^{\prime}$ is the total number of data used and $p$ is the number of parameters to be estimated.
To evaluate the possible existence of bias, the linear model $Z_{i}=a \cdot \hat{Z}_{i}+b([20,41])$ was fitted, and a F-test was used to check the null hypothesis (the absence of bias) i.e. that the slope of the straight line was equal to 1 at the same time as the independent term (b) was equal to 0 .

\section{RESULTS}

\subsection{Model fitting phase}

In order to be able to interpret and compare the results more easily and because of the large number of equations analysed, the models were classified in three groups according to the sampling effort, as pointed out in the Materials and Methods section above.

Tables $I V, V$ and $V I$ show the values of the statistics used to compare the models in the fitting phase and in the crossvalidation for the groups 1,2 and 3 respectively.

The results of fitting and cross-validation for the models of group 1 are the poorest, as could be expected. The use of independent variables related only with either the diametrical distribution or with the age of the stand does not appear to be sufficient explanation for the variability observed on height values. Therefore, it is advisable the inclusion of an additional variable in order to improve the estimates.

Finally, it's important to emphasise the poor behaviour of the model of Clutter and Allison [10], in spite of this model was used to estimate the height of individual trees in a growth model for Pinus radiata in New Zealand.

The values of the statistics of the models included in the group 2 (table $V$ ) show that the second modification of the Cox [11] model (Cox II, Mod. 2) is the equation of this group that most accurately estimates the height. This equation improves the accuracy of the first modification (Cox II, Mod. 1) due to the lack of restrictions for the values of the exponent of the independent variables. Only the exponent affecting $d_{\mathrm{g}}$ has been restricted, due to a lack of convergence. The good results obtained with this model are consistent with those obtained by Cox [11] for the same species (Pinus radiata) in Chile.

The models of Møness [30] and Cañadas et al. IV [8] also fit well to the data. The advantage of these models is that they are functions of one single parameter, although the bias and $M S E$ were slightly higher than those of the modified versions of the model of Cox II [11]. 
Table V. Values of the statistics for fitting and cross-validation for group 2 models.

\begin{tabular}{|c|c|c|c|c|c|c|c|c|c|c|c|}
\hline \multirow[t]{3}{*}{ MODELS } & \multicolumn{5}{|c|}{ FIT } & \multicolumn{6}{|c|}{ CROSS - VALIDATION } \\
\hline & \multirow[t]{2}{*}{ Variables } & \multirow[t]{2}{*}{$R_{\text {adj }}^{2}$} & \multirow[t]{2}{*}{ Bias } & \multirow[t]{2}{*}{$M S E$} & \multirow[t]{2}{*}{$\Delta_{i}$} & \multirow[t]{2}{*}{$\mathrm{MEF}_{\text {adj }}$} & \multicolumn{2}{|c|}{ pred. vs. obs. F-Test } & \multirow[t]{2}{*}{ Bias } & \multirow[t]{2}{*}{$M S E$} & \multirow[t]{2}{*}{$\Delta_{i}$} \\
\hline & & & & & & & F VAL. & $\overline{\operatorname{Pr}>F}$ & & & \\
\hline Mønness [30] & $d, D_{0}, H_{0}$ & 0.9130 & 0.0399 & 3371 & 558.7367 & 9129 & 42.29 & $<0.0001$ & 0.0399 & 3.3382 & 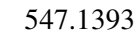 \\
\hline Cañadas et al. I [8] & $d, D_{0}, H_{0}$ & 0.9093 & 0.0909 & 3.4771 & 956.7995 & 0.9093 & 142.46 & $<0.0001$ & 0.0908 & 3.4782 & 946.119 \\
\hline Cañadas et al. II [8] & $d, D_{0}, H_{0}$ & 0.8895 & 0.5730 & 4.2357 & 2869.4106 & 0.8904 & 748.95 & $<0.0001$ & 0.5728 & 4.2391 & 2862.233 \\
\hline Cañadas et al. III [8] & $d, D_{0}, H_{0}$ & 0.9090 & 0.1743 & 3.4893 & 991.6849 & 0.9090 & 167.04 & $<0.0001$ & 0.1742 & 3.4908 & 981.0705 \\
\hline al. IV [8] & $d, D_{0}, H_{0}$ & 0.9145 & 0.0361 & 3.2760 & 379.8576 & 0.9145 & 6.06 & 0.0023 & 0.0361 & 3.2771 & 368.2144 \\
\hline Gaffr & $d, d_{\mathrm{g}}, H_{0}$ & 0.7772 & 3 & 8.5411 & 9662.6009 & 0.8020 & 6666.1 & $<0.0$ & 7 & 8.5448 & 965 \\
\hline Sloboda et al. [38] & $d, d_{\mathrm{g}}, H_{\mathrm{m}}$ & 0.8765 & -0.0258 & 4.7334 & 3945.4715 & 0.8764 & 1.46 & 0.2328 & -0.0259 & 4.7374 & 3940.9090 \\
\hline Harrison et al. [16] & $d, H_{0}$ & 0.8992 & -0.0307 & 3.8654 & 1987.2401 & 0.8991 & 10.46 & $<0.0001$ & -0.0307 & 3.8681 & 1979.2874 \\
\hline Castedo et al. [9] Mod. & $d, H_{0}$ & 0.8575 & -0.0336 & 5.4655 & 5339.3047 & 0.8573 & 8.9 & 0.0001 & -0.0339 & 5.4720 & 5336.1777 \\
\hline Pienaar [33] Mod. & $d, d_{\mathrm{g}}, H_{0}$ & 0.9039 & -0.0960 & 3.6846 & 1520.2139 & 0.9038 & 132.39 & $<0.0001$ & -0.0960 & 3.6873 & 1512.5555 \\
\hline Hui and Gadow [21] & $d, H_{0}$ & 0.8858 & -0.0160 & 4.3818 & 3203.8350 & 0.8856 & 2.41 & 0.0896 & -0.0162 & 4.3860 & 3198.4347 \\
\hline Mirkovich [29] & $d, d_{\mathrm{g}}, H_{0}$ & 0.9055 & 0.0273 & 3.6246 & 1362.2359 & 0.9054 & 8.18 & 0.0003 & 0.0273 & 3.6283 & 1357.3113 \\
\hline Schröder and Álvarez I, [37] & $d, d_{\mathrm{g}}, H_{0}$ & 0.9106 & -0.0041 & 3.4291 & 825.0991 & 0.9105 & 0.19 & 0.8285 & -0.0041 & 3.4325 & 820.0672 \\
\hline Cox III [11] Mod. & $d, d_{\mathrm{g}}, H_{\mathrm{m}}, N$ & 0.8763 & -0.0032 & 4.7428 & 3967.6250 & 0.8761 & 0.1 & 0.9085 & -0.0036 & 4.7503 & 3973.1747 \\
\hline Schröder and Álvarez II [37] & $d, G, d_{\mathrm{g}}, H_{0}$ & 0.9106 & -0.0041 & 3.4292 & 826.3648 & 0.9104 & 0.19 & 0.8271 & -0.0042 & 3.4335 & 823.9297 \\
\hline Cox II [11] Mod. 1 & $d, d_{\mathrm{g}}, H_{\mathrm{m}}$ & 0.9135 & 0.0000 & 3.3168 & 504.6334 & 0.9133 & 0 & 0.9993 & 0.0002 & 3.3232 & 508.4968 \\
\hline Cox II [11] Mod. 2 & $d, d_{\mathrm{g}}, H_{\mathrm{m}}$ & 0.9156 & 0.0000 & 3.2367 & 270.9605 & 0.9153 & 0.00 & 0.9986 & 0.0001 & 3.2453 & 281.8632 \\
\hline
\end{tabular}

Table VI. Values of the statistics for fitting and cross-validation for group 3 models.

\begin{tabular}{|c|c|c|c|c|c|c|c|c|c|c|c|}
\hline \multirow[t]{3}{*}{ MODELS } & \multicolumn{5}{|c|}{ FIT } & \multicolumn{6}{|c|}{ CROSS - VALIDATION } \\
\hline & \multirow[t]{2}{*}{ Variables } & \multirow[t]{2}{*}{$R_{\text {adj }}^{2}$} & \multirow[t]{2}{*}{ Bias } & \multirow[t]{2}{*}{$M S E$} & \multirow[t]{2}{*}{$\Delta_{i}$} & \multirow[t]{2}{*}{$M E F_{\text {adj }}$} & \multicolumn{2}{|c|}{ pred. vs. obs. F-Test } & \multirow[t]{2}{*}{ Bias } & \multirow[t]{2}{*}{$M S E$} & \multirow{2}{*}{$\Delta_{i}$} \\
\hline & & & & & & & F VAL. & $\operatorname{Pr}>F$ & & & \\
\hline Tomé [40] & $d, D_{0}, H_{0}, t, N$ & 0.9179 & -0.0028 & 3.1491 & 0.0000 & 0.9178 & 0.21 & 0.812 & -0.0029 & 3.1526 & 0.0000 \\
\hline Bennet and Clutter [5] & $d, t, N, I S$ & 0.8574 & 0.0379 & 5.4701 & 5349.6127 & 0.8568 & 12.8 & $<0.0001$ & 0.0382 & 5.4896 & 5369.1342 \\
\hline Lenhart [27] & $d, H_{0}, t, N, D_{\max }$ & 0.9118 & 0.0221 & 3.3821 & 697.4526 & 0.9117 & 6.61 & 0.0013 & 0.0221 & 3.3865 & 695.4285 \\
\hline Amateis et al. [1] & $d, H_{0}, t, N, D_{\max }$ & 0.9113 & 0.0107 & 3.4028 & 751.6177 & 0.9110 & 1.63 & 0.196 & 0.0105 & 3.4108 & 759.5348 \\
\hline Burkhart and Strub [6] & $d, H_{0}, t, N$ & 0.9065 & 0.0152 & 3.5857 & 1259.8154 & 0.9063 & 3.02 & 0.049 & 0.0150 & 3.5914 & 1260.2069 \\
\hline Pascoa [32] & $d, H_{0}, t, G$ & 0.9005 & 0.0399 & 3.8157 & 1861.7774 & 0.9003 & 19.03 & $<0.0001$ & 0.0397 & 3.8220 & 1863.1169 \\
\hline
\end{tabular}

The six models classified in group 3 (table VI) have similar results to those of group 2, although the model of Tomé [40] gives the best performance of all the models tested, according to the values of the statistics used to compare the models in the fitting phase and the cross-validation. The results were slightly better than those obtained with the model of Cox II [11] when the values of the exponents of the independent variables were not restricted.

Plot of residuals versus the heights predicted in the fitting phase of the model of Tomé [40] are shown in figure 1. There was no reason to reject the hypotheses of normality, homogeneity of variance and independence of residuals.

Plot of the observed heights versus the predicted heights in the cross-validation of this model are shown in figure 2 . The criterion to evaluate the behaviour of the model was the determination coefficient of the straight line fitted between the observed and predicted heights. The chart shows no tendency toward the overestimation or underestimation of height values.

To analyse the behaviour of the two best models (Tomé [40] and Cox II [11] Mod. 2) the values of the bias and the 


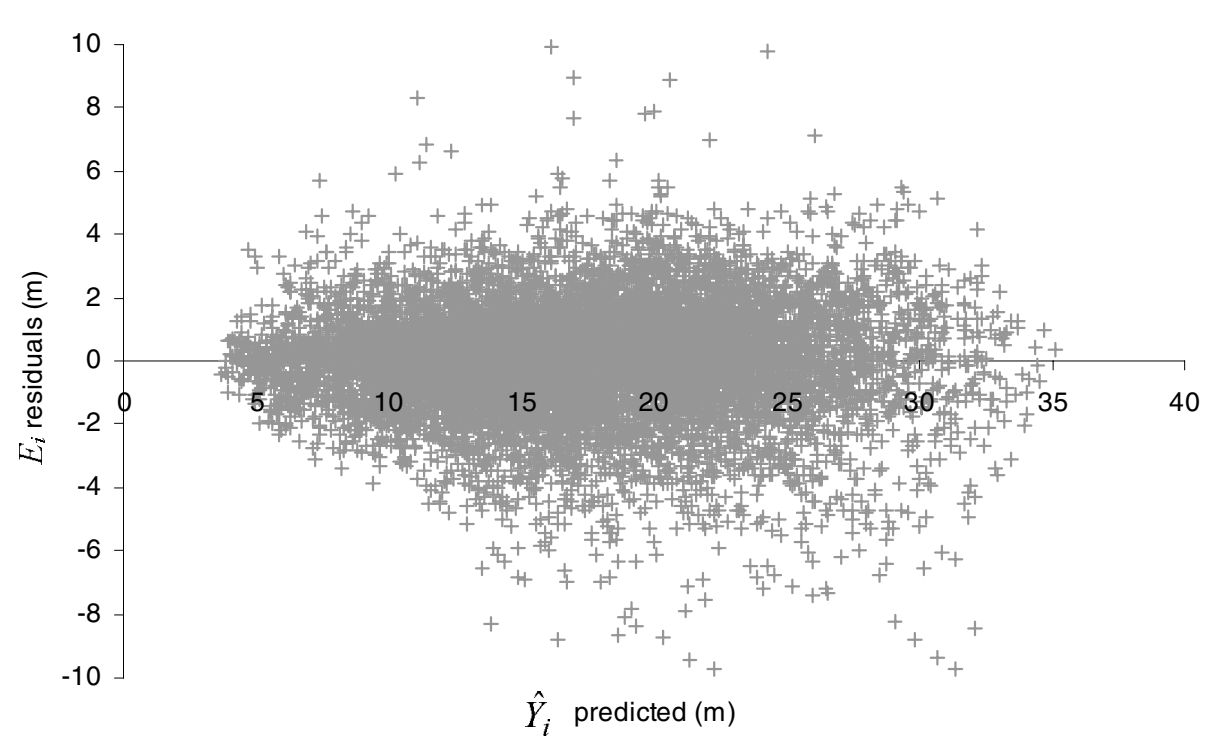

Figure 1. Plot of residuals versus predicted values in the fitting phase for the model of Tomé [40].

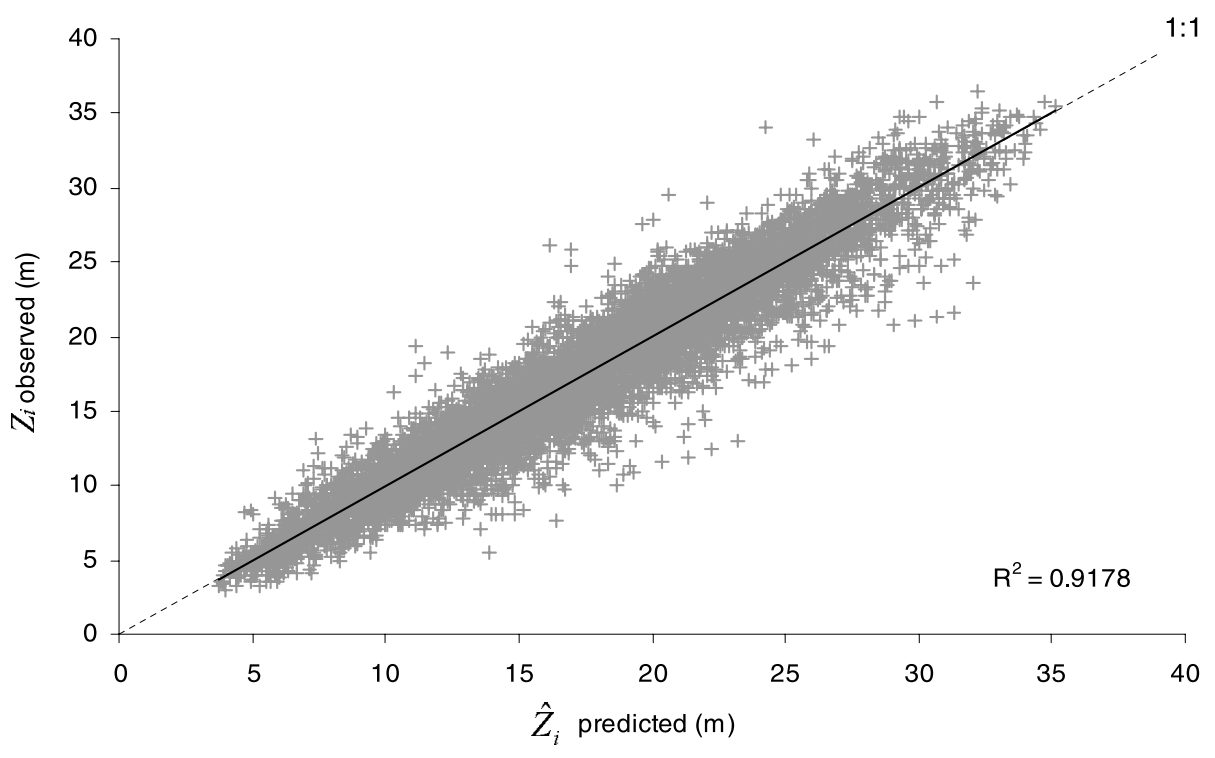

Figure 2. Plot of observed values versus predicted values in the cross-validation for model of Tomé [40]. The solid line represents the linear model fitted to the scatter plot of data. The dotted line represents the diagonal.

mean square error were calculated and plotted against diameter classes, for the fitting phase and the cross-validation. (figures 3 and 4).

Despite a slight trend to overestimation for the higher diameter classes, the model proposed by Tomé [40], which includes five independent variables, gives a better performance.

The good performance of this model may be due, in part, to the inclusion of the stand age, which is an important variable in the consideration of even-aged, uniform stands [8] (which the stands in plantations usually are) because, in these cases, the age gives an indication of the mean size of the individual trees in the stand.

In general, the inclusion of new independent variables in the height-diameter equation reduced bias and increased the precision of the model. However, the increase in accuracy of the estimations is usually associated with a larger sampling 
(a)

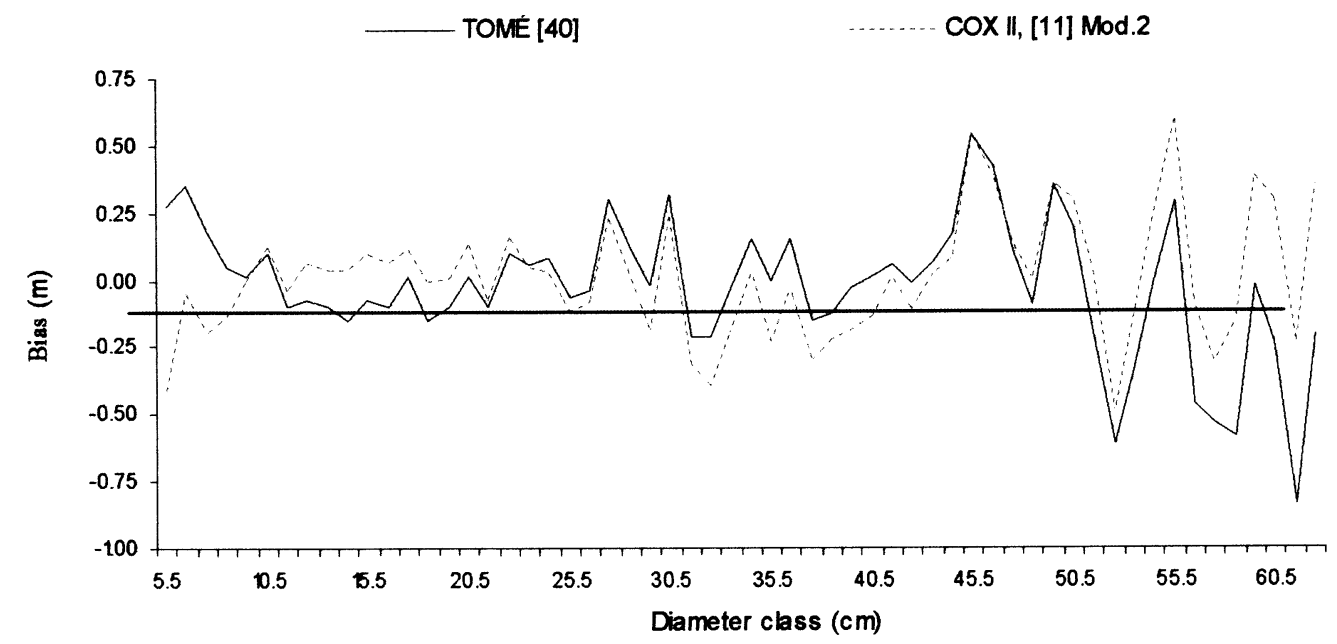

(b)

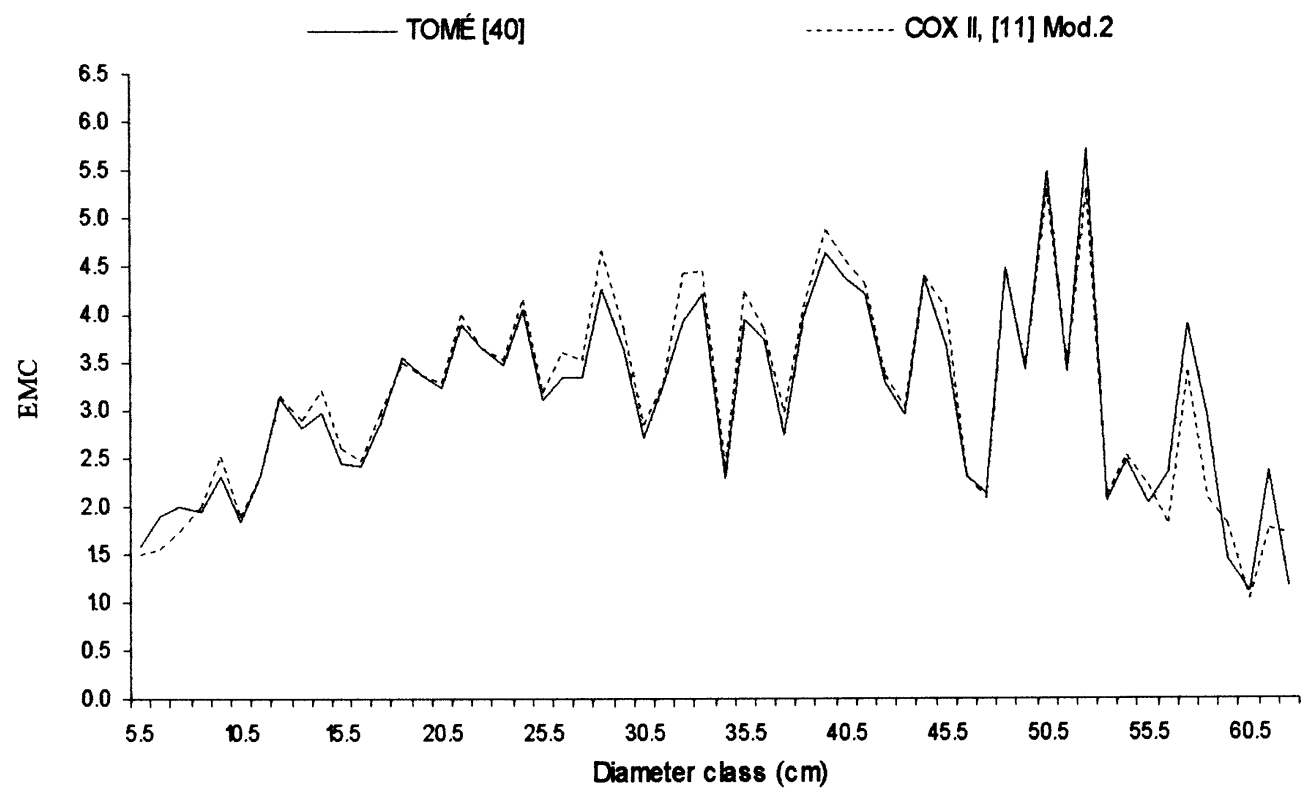

Figure 3. Values of (a) bias and (b) mean square error obtained for diameter classes in the fitting phase of the two best models (Tomé [40] and Cox II [11] Mod. 2).

effort due to the greater number of independent variables that must be measured in the field. The model of Tomé [40] could offer a balance between the accuracy of the model and the sampling effort, because the value of age is well-known if the date of plantation is available.

\section{CONCLUSIONS}

The inclusion of the mean height or of the dominant height as an independent variable in the height-diameter equations appears to be necessary in order to achieve acceptable predictions. This requires the measurement of at least one sample of heights for the practical application of the equation.

The best predictions of height were obtained by the model of Tomé [40], which uses diameter $(d)$, dominant diameter $\left(D_{0}\right)$, dominant height $\left(H_{0}\right)$, age $(t)$ and number of trees per hectare $(N)$ as independent variables; this was followed in performance by the modified version 2 of the model of Cox II [11], which depends on three variables $\left(d, d_{\mathrm{g}}, H_{\mathrm{m}}\right)$.

Aknowledgements: This study was financed by the Comisión Interministerial de Ciencia y Tecnología (CICYT) and the European Commission, project No 1FD97-0585-C03-03. 
(a)

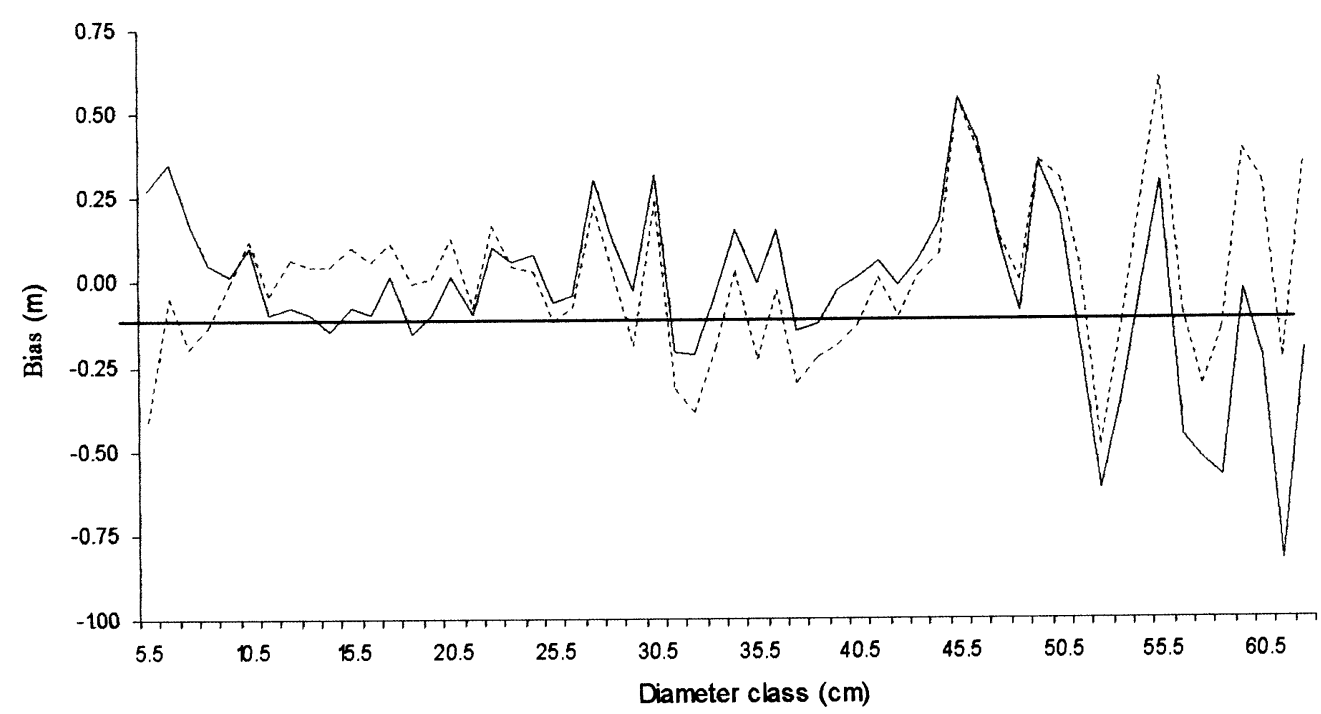

(b)

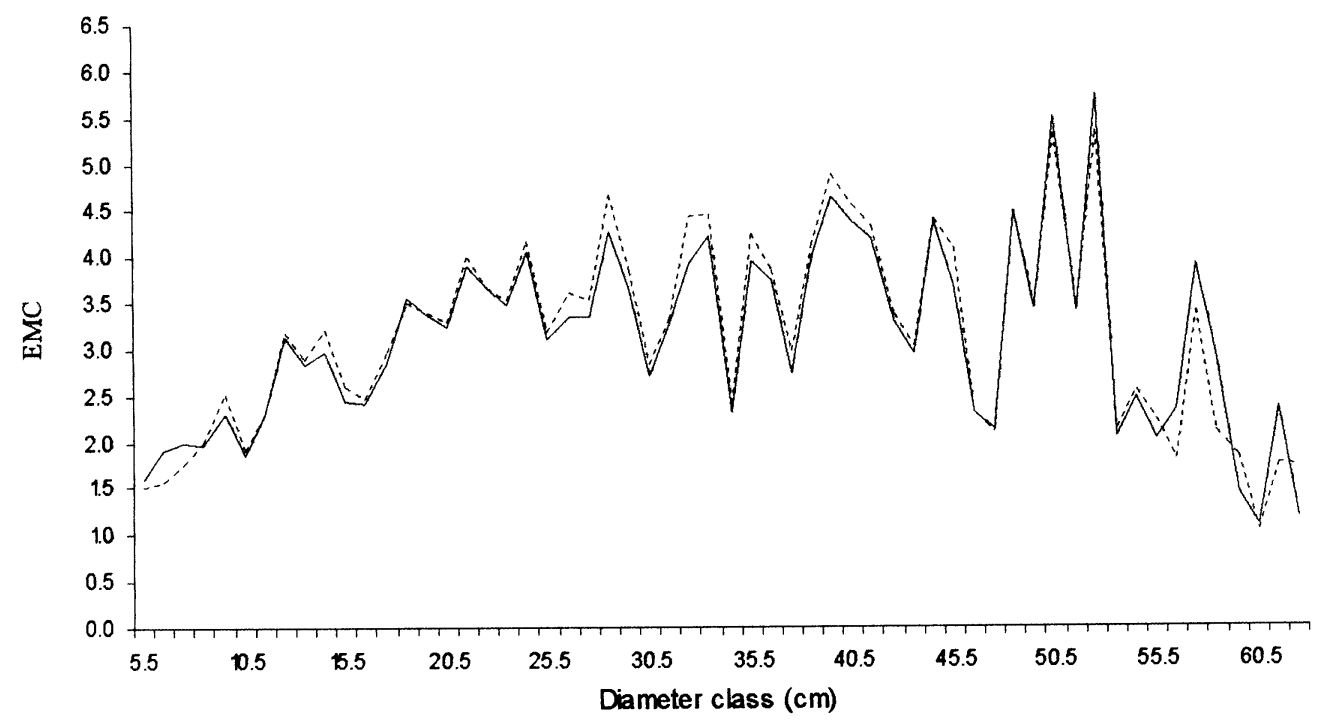

Figure 4. Values of (a) bias and (b) mean square error obtained for diameter classes in the cross-validation of the two best models (Tomé [40] and Cox II [11] Mod. 2).

\section{REFERENCES}

[1] Amateis R.L., Burkhart H.E., Zhang S., TRULOB: Tree Register Updating for Loblolly Pine (an individual tree growth and yield model for managed loblolly pine plantations). Coop. Rep. 83 Blacksburg, VA: Virginia Polytechnic Institute and State University, Departament of Forestry, Loblolly Pine Growth and Yield Cooperative, 1995.

[2] Assmann E., Untersuchungen über die Höhenkurven von Fichtenbeständen, AFJZ, 1943.

[3] Assmann E., The principles of Forest Yield Study, Pergamon Press, Oxford, 1970
[4] Bailey R.L., Brooks J.R., Determining site index and estimating timber volumes without measuring heights, South. J. Appl. For. 18 (1994) 15-18.

[5] Bennett F.A., Clutter J.L., Multiple-product yield estimates for unthinned slash pine plantations-pulpwood, sawtimber, gum, U.S.D.A. For. Serv. Res. Pap. SE-35, 1968.

[6] Burkhart H.E., Strub M.R., A model for simulation of planted loblolly pine stands, in: Fries J. (Ed.), Growth Models for Tree and Stand Simulation, Royal College of Forestry, Research Note 30, Stockholm, 1974, pp. 128-135.

[7] Burnham K.P., Anderson D.R., Model selection and inference: a practical information-theoretic approach, Springer-Verlag, New York, 1998. 
[8] Cañadas N., García C., Montero G., Relación altura-diámetro para Pinus pinea L. en el Sistema Central, in: Actas del Congreso de Ordenación y Gestión Sostenible de Montes, 1999 (in press).

[9] Castedo F., Ruiz A.D., Álvarez González J.G., Modelización de la relación altura-diámetro para Pinus pinaster Ait. en Galicia mediante la función de densidad bivariante $\mathrm{S}_{\mathrm{BB}}$, Investigación Agraria, Sistemas y Recursos Forestales 10 (2001) 111-126.

[10] Clutter J.L., Allison B.J., A growth and yield model for Pinus radiata in New Zealand, in: Fries J. (Ed.), Growth Models for Tree and Stand Simulation, Royal College of Forestry, Research Note 30, Stockholm, 1974, pp. 136-160.

[11] Cox F., Modelos parametrizados de altura, Informe de convenio de investigación interempresas, 1994.

[12] Curtis R.O., Height-diameter and height-diameter-age equations for second-growth Douglas-fir, For. Sci. 13 (1967) 365-375.

[13] Curtis R.O., Stand density measures: an interpretation, For. Sci. 16 (1970) 303-314.

[14] Gadow K.V., Waldwachstum. Beilage zur Vorlesung für das Sommersemester. Universität Göttingen, 2001.

[15] Gaffrey D., Forstamts-und bestandesindividuelles Sortimentierungsprogramm als Mittel zur Planung, Aushaltung und Simulation. Diplomarbeit Forscliche Fakultät, Universität Göttingen, 1988.

[16] Harrison W.C., Burk T.E., Beck D.E., Individual tree basal area increment and total height equations for Appalachian mixed hardwoods after thinning, South. J. Appl. For. 10 (1986) 99-104.

[17] Hartley H.O., The modified Gauss-Newton method for the fitting of nonlinear regression functions by least squares, Technometrics 3 (1961) 269-280.

[18] Hohenadl W., Die Bestandesmessung, Fw. Cbl., 1936.

[19] Huang S., Titus S.J., Wiens D., Comparison of nonlinear heightdiameter functions for major Alberta tree species, Can. J. For. Res. 22 (1992) 1297-1304.

[20] Hui G., Gadow K.v., Modelling Forest Development, Kluwer Academic Publishers, 1999.

[21] Hui G., Gadow K.v., Zur Entwicklung von Einheitshöhenkurven am Beispiel der Baumart Cunninghamia lanceolata, AFJZ 164 (1993) 218-220.

[22] Johnson N.L., Bivariate distributions based on simple translation systems, Biometrika 36 (1949) 297-304.

[23] Krenn K., Die Bestandesmassenermittlung mit Hilfe stehender Probestämme, Frankfurt/M., 1944.

[24] Lappi J., A longitudinal analysis of Height/Diameter curves, For. Sci. 43 (1997) 555-570.

[25] Larsen D.R., Hann D.W., Height-diameter equations for seventeen tree species in southwest Oregon, Oreg. State. Univ. For. Res. Lab. 46, 1987.
[26] Laar A.v., Akça A., Forest Mensuration. 1. Aufl., Cuvillier Verlag, Göttingen, 1997.

[27] Lenhart J.D., Yield of old-field loblolly pine plantations in the Georgia Piedmont, Ph. D. Thesis, Univ. Ga., Athens, 1968.

[28] Michailoff J.L., Über die Anwendung der Methode der Kleinsten Quadrate bei der Aufstellung von Massentafeln mit einem Eingange, Skopie, 1951.

[29] Mirkovich J.L., Normale visinske krive za chrast kitnak i bukvu v NR Srbiji. Zagreb. Glasnik sumarskog fakulteta 13, 1958.

[30] Mønness E.N., Diameter distributions and height curves in evenaged stands of Pinus sylvestris L., Medd. No. Inst. Skogforsk 36 (1982) $1-43$.

[31] Naslund M., Die Durchforstungsversuche der forstlichen Versuchsanstalt Schwedens im Krefernwald, M.S.S., 1937.

[32] Pascoa F., Estructura, crecimento e produçao em povoamentos de pinheiro bravo. Um modelo de simulaçao, Ph. D. thesis, Universidade Técnica de Lisboa, 1987.

[33] Pienaar L.V., PMRC Yield Prediction System for Slash Pine Plantations in the Atlantic Coast Flatwoods, PMRC Technical Report, Athens, 1991.

[34] Prodan M., Peters R., Cox F., Real P., Mensura Forestal. Instituto Interamericano de Cooperación para la Agricultura (IICA), Costa Rica, 1997.

[35] Sánchez F., Rodríguez R., Rojo A., Álvarez J., Resultados preliminares del estudio de curvas de calidad de estación y de los factores ecológicos implicados en la productividad de Pinus radiata D. Don en Galicia (España), in: Actas del Primer Congreso Latinoamericano IUFRO: "El manejo sustentable de los recursos forestales, desafío del siglo XXI", 1998.

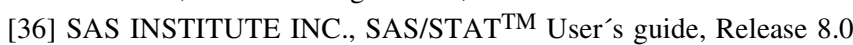
Edn, Cary, NC, USA, 1999.

[37] Schröder J., Álvarez González J.G., Developing a generalized diameter-height model for maritime pine in Northwestern Spain, Forstwissenschaftliches Centralblatt 120 (2001) 18-23.

[38] Sloboda V.B., Gaffrey D., Matsumura N., Regionale und lokale Systeme von Höhenkurven für gleichaltrige Waldbestände, Allg. Forst. Jagdztg. 164 (1993) 225-228.

[39] Speidel E., Beiträge zu den Wuchsgesetzen des Hochwaldes und der Durchforstunsglehre, Tübingen, 1983.

[40] Tomé M., Modelaçao do crescimento da árvore individual em povoamentos de Eucalyptus globulus Labill. ( $1^{\mathrm{a}}$ rotaçao) na regiao centro de Portugal, Ph. D. Thesis, Instituto Superior de Agronomía, Lisboa, Portugal, 1989.

[41] Vanclay J.K., Modelling forest growth-applications to mixed tropical forests, CAB International, Wallingford, 1994.

[42] Zhang S.A., Burkhart H.E., Amateis R.L., The influence of thinning on tree height and diameter relationships in loblolly pine plantations, South. J. Appl. For. 21 (1997) 199-205. 